\title{
THE STUDY OF INFLUENCE OF PLATELET DYSFUNCTION ON CLINICAL PHENOTYPE OF HEMOPHILIA
}

\author{
By \\ Mohammed Khalil Mohammed Abdalla, Mahmoud Mohammed Mousa \\ Bazeed, Mahmoud Abdeirashed Abdelkhalek and Ahmed Ali Ali Assem* \\ Departments of Internal Medicine and Clinical Pathology*, Faculty of Medicine, Al-Azhar \\ University \\ E-mail: $\underline{\text { dr4667294@gmail.com }}$
}

\begin{abstract}
Background: Hemophilia is an X-linked heritable coagulopathy with an overall prevalence of approximately 1 in 10,000 individuals. Hemophilias are rare X linked hereditary bleeding disorders. Platelets may be among the determinants of variability in bleeding phenotype.

Objective: To evaluate the platelet function tests in patients with hemophilia, and to explore the influence of platelet dysfunction on hemophilia bleeding score.

Patients and Methods: The study was conducted on 40 hemophilic patients and 20 normal persons as a control in outpatient clinics at Kafr El-Sheikh Governorate Hospitals and Al-Azhar University Hospitals (AlHussein and Sayed Galal) to evaluate the platelet function tests in patients with hemophilia, and to explore the influence of platelet dysfunction on hemophilia bleeding score.

Results: The majority of cases (35 patients $87.5 \%$ ) were type A and (5 patients $12.5 \%$ ) were type B. As regard to hemophilia scoring system (HSS), 3 patients (7.5\%) were type 1, 19 patients (47.5\%) were type 2 and 18 patients $(45 \%)$ were type 3 . Bleeding from the knee occurred in the majority of patients $(77.5 \%)$, from the elbow occurred in $32.5 \%$, from the ankle occurred in 5\%, from the vagina occurred in $15 \%$ and from the nose and the gum occurred in $7.5 \%$. Platelets and maual platelet count showed insignificant difference between both groups. Platelets aggregation tests (ADP) test, collagen and restocetin agonists test) were significantly lower in cases group than control group. Prothrombin time (PT), international normalized ratio (INR), bleeding time (BT) showed insignificant differences between both group. On the other hands, activated partial thromboplastin time (APTT) significantly prolonged cases group than control group. No hemophilia $\mathrm{C}$ cases were detected in our study.
\end{abstract}

Conclusion: There was a statistical significant relationship between bleeding phenotype in hemophilia B and platelet function. Diagnosis of hemophilia was confirmed by factor VIII assay for hemophilia A and factor IX assay for hemophilia B.

Keywords: Hemophilia, Platelet Dysfunction, Clinical Phenotype.

\section{INTRODUCTION}

Although many patients with hemophilia may have exactly the same residual clotting factor level, the clinical disease phenotype may vary greatly. This variation may be related to different genetic mutations responsible for hemophilia, environmental influences and co-inheritance of polymorphisms affecting the coagulation system in hemophilia (Traivaree et al., 2011). 
While thrombin generation is severely impaired in persons with hemophilia, primary hemostasis, i.e. platelet function, has been generally considered to be normal. However, some studies reported prolonged bleeding times in hemophilia, suggesting that also primary hemostasis is affected (Faircloth et al., 2017).

An influence of platelet function on clinical phenotype was suggested, which might contribute in part to variations in bleeding tendency in hemophilic patients with similar factor levels. However, the available evidence is currently limited and no clear correlations between platelet function parameters and clinical phenotypes have been demonstrated. The impact of alterations of platelet function in hemophilia remains to be better defined. Another interesting role of platelets in hemophilia has been reported recently by establishing a novel gene-therapeutic strategy using platelets as a delivery system for FVIII, showing promising results in animal models. This review gives an overview on the currently published literature on platelet function and the potential roles of platelets in hemophilia (Lyde et al., 2015).

The primary goal of this study was to evaluate the platelet function tests in patients with hemophilia and to explore the influence of platelet dysfunction on hemophilia bleeding score.

\section{PATIENTS AND METHODS}

The study was conducted on 40 hemophilic patients and 20 normal persons as a control in outpatient clinics at Kafr El-Sheikh Governorate Hospitals and Al-Azhar university Hospitals (ALHussein and Sayed Galal) to evaluate the platelet function tests in patients with hemophilia and to explore the influence of platelet dysfunction on hemophilia bleeding score. The population of the study included patients suffering from Hemophilia A and B aged (12-50) years old.

\section{Inclusion criteria:}

- Known patients with Hemophilia A and $\mathrm{B}$.

- Age between 12 - 50 years.

- Patients not receiving anti platelet drugs.

\section{Exclusion criteria:}

- Patients complaining from Hemophilia aged less than 12 years and more than 50 years.

- Patients with splenomegaly.

- Patients with chronic liver diseases.

- Patients with chronic renal diseases.

- Patients with cardiac diseases that receiving antiplatelet drugs.

Ethics and Patient Consent: All the procedure followed Al Azhar University ethics committee regulations. An informed written consent was taken from every patient before collecting any information or starting any procedure.

\section{Hemophilia scoring system:}

1. Age at first joint bleed or arthropathy.

2. Treatment requirement (i.e. annual clotting factor use).

3. Annual bleeding frequency.

\begin{tabular}{|c|c|c|c|}
\hline Group & A & B & C \\
\hline Score & 3 & 2 & 1 \\
\hline
\end{tabular}




\section{Investigations done:}

1. Complete Blood Count.

2. Manual platelet count.

3. Platelet aggregation tests by using platelet aggregometry with ADP, Collagen and Ristocetin agonists.

4. Prothrombin time (PT), international normalization ratio (INR).

5. Bleeding time (BT).

6. Activated partial thromboplastin time (aPTT).

7. Measurement of FVIII activity in homphilia type A cases.

8. Measurement of FIX activity in homphilia type B cases.

\section{Statistical analysis:}

Statistical analysis was done by SPSS v25 (IBM Inc., Chicago, IL, USA). Normality of data was checked with Shapiro-Wilks test and hsitograms. Numerical variables with normal distribution were presented as mean, standard deviation (SD), range and compared between the two groups utilizing Student's t- test. . Numerical variables with abnormal distribution were presented as median, range and compared between the two groups utilizing MannWhitney (U) test. Categorical variables were presented as frequency and percentage (\%) and were analysed utilizing the Chi-square test or Fisher's exact test when appropriate. $\mathrm{P}$ value < 0.05 was considered significant.

\section{RESULTS}

The study was conducted on 40 hemophilic patients and 20 normal persons as a control in outpatient clinics at Kafr El-Sheikh Governorate Hospitals (Al Obour Hospital and Kafr El-Sheikh
General Hospital) and Al-Azhar university Hospitals (Al-Hussein and Sayed Galal).

Patients' characteristics (age, sex and weight) showed insignificant difference in both groups $(\mathrm{P}=0.683,0.552$ and 0.082 respectively) (Table 1).

Table (1): Patients' characteristics in both groups

\begin{tabular}{|c|c|c|c|c|}
\hline \multicolumn{2}{|c|}{$\begin{array}{ll}\text { Parameters } & \text { Groups } \\
\end{array}$} & $\begin{array}{c}\text { Cases } \\
(n=40)\end{array}$ & $\begin{array}{l}\text { Control } \\
(\mathbf{n}=\mathbf{2 0})\end{array}$ & $P$ value \\
\hline \multirow{2}{*}{$\begin{array}{c}\text { Age } \\
\text { (years) }\end{array}$} & Mean \pm SD & $22.45 \pm 11.7$ & $23.6 \pm 6.11$ & \multirow{2}{*}{$>0.05^{\#}$} \\
\hline & Range & $12-44$ & $14-30$ & \\
\hline \multirow{2}{*}{ Sex } & Male & $31(77.5 \%)$ & $16(80 \%)$ & \multirow{2}{*}{$>0.05$} \\
\hline & Female & $9(22.5 \%)$ & $4(20 \%)$ & \\
\hline \multirow{2}{*}{$\begin{array}{c}\text { Weight } \\
\text { (kg) }\end{array}$} & Mean \pm SD & $56.93 \pm 21.48$ & $67.1 \pm 20.05$ & \multirow{2}{*}{$>0.05^{\#}$} \\
\hline & Range & $29-100$ & $35-95$ & \\
\hline
\end{tabular}


As regard to type of hemophilia, 35 patients $(87.5 \%)$ were type $\mathrm{A}$ and 5 patients $(12.5 \%)$ were type B. As regard to HSS, 3 patients $(7.5 \%)$ were type 1,19 patients $(47.5 \%)$ were type 2 and 18 patients $(45 \%)$ were type 3 . As regard to site of bleeding, bleeding from the knee occurred in 31 patients $(77.5 \%)$, from the elbow occurred in 13 patients $(32.5 \%)$, from the ankle occurred in 2 patients $(5 \%)$, from the vagina occurred in 6 patients $(15 \%)$ and from the nose and the gum occurred in 3 patients $(7.5 \%)$ (Table 2).

Table (2): Type of hemophilia, HSS and site of bleeding in the cases group

HSS: Hemophilia scoring system

\begin{tabular}{|c|c|c|}
\hline \multicolumn{2}{|c|}{} & Cases $(\mathbf{n}=\mathbf{4 0})$ \\
\hline \multirow{3}{*}{ Type of hemophilia } & A & $35(87.5 \%)$ \\
\cline { 2 - 3 } Hemophilia scoring system & B & $5(12.5 \%)$ \\
\hline \multirow{5}{*}{ Site of bleeding } & Type 1 & $3(7.5 \%)$ \\
\cline { 2 - 3 } & Type 2 & $19(47.5 \%)$ \\
\cline { 2 - 3 } & Type 3 & $18(45.0 \%)$ \\
\hline & Knee & $31(77.5 \%)$ \\
\cline { 2 - 3 } & Elbow & $13(32.5 \%)$ \\
\cline { 2 - 3 } & Ankle & $2(5 \%)$ \\
\cline { 2 - 3 } & Vaginal & $6(15 \%)$ \\
\cline { 2 - 3 } & Nose & $3(7.5 \%)$ \\
\cline { 2 - 3 } & Gum & $3(7.5 \%)$ \\
\hline
\end{tabular}

TLC, platelets and maual platelet count showed insignificant difference between both groups $(\mathrm{P}$ value $=0.541,0.057$ and
0.481). Hemoglobin was significantly lower in the cases group than the control group $(\mathrm{P}<0.001)$ (Table 3).

Table (3): Complete blood count (CBC) in both groups

\begin{tabular}{|c|c|c|c|c|}
\hline \multicolumn{2}{|c|}{$\begin{array}{ll}\text { Parameters } & \text { Groups } \\
\end{array}$} & $\begin{array}{c}\text { Cases } \\
(n=40)\end{array}$ & $\begin{array}{l}\text { Control } \\
(\mathbf{n}=20)\end{array}$ & $P$ value \\
\hline \multirow{2}{*}{$\begin{array}{c}\text { Hemoglobin } \\
\text { (g/dL) }\end{array}$} & Mean \pm SD & $10.12 \pm 1.63$ & $13.8 \pm 1.32$ & \multirow{2}{*}{$<0.001$} \\
\hline & Range & $7.2-13$ & $12-16$ & \\
\hline \multirow{2}{*}{$\begin{array}{c}\text { TLC } \\
\left(* 10^{3} / \mathbf{m m}^{3}\right)\end{array}$} & Mean \pm SD & $9.03 \pm 2.02$ & $9.38 \pm 2.15$ & \multirow{2}{*}{$>0.05$} \\
\hline & Range & $6-13.3$ & $4.3-12$ & \\
\hline \multirow{2}{*}{$\begin{array}{c}\text { Platelets } \\
\left(* 10^{3} / \mathbf{m m}^{3}\right)\end{array}$} & Mean \pm SD & $196.03 \pm 73.17$ & $238 \pm 89.54$ & \multirow{2}{*}{$>0.05^{\#}$} \\
\hline & Range & $100-329$ & $180-410$ & \\
\hline \multirow{2}{*}{$\begin{array}{c}\text { Manual } \\
\text { platelets count } \\
\left(* 10^{3} / \mathbf{m m}^{3}\right) \\
\end{array}$} & Mean \pm SD & $229.83 \pm 78.51$ & $243.6 \pm 52.22$ & \multirow{2}{*}{$>0.05^{\#}$} \\
\hline & Range & $130-411$ & $180-326$ & \\
\hline
\end{tabular}

TLC: Total leucocytic count \# compared by Mann-Whitney test

Platelets aggregation tests (ADP, collagen and restocetin agonists) were significantly lower in cases group than control group $(\mathrm{P}=0.016,0.011$ and 0.049 respectively) (Table 4). 
Table (4): Platelets aggregation tests in both groups

\begin{tabular}{|c|c|c|c|c|}
\hline \multicolumn{2}{|c|}{$\begin{array}{ll}\text { Parameters } & \text { Groups } \\
\end{array}$} & $\begin{array}{c}\text { Cases } \\
(n=40)\end{array}$ & $\begin{array}{l}\text { Control } \\
(\mathbf{n}=\mathbf{2 0})\end{array}$ & $P$ value \\
\hline \multirow{2}{*}{ ADP test } & Mean \pm SD & $52.65 \pm 21.9$ & $68 \pm 23.87$ & \multirow{2}{*}{$0.016^{*}$ \# } \\
\hline & Range & $10-84$ & $22-85$ & \\
\hline \multirow{2}{*}{ Collagen test } & Mean \pm SD & $61.98 \pm 18.07$ & $75.4 \pm 25.38$ & \multirow{2}{*}{0.011 * \# } \\
\hline & Range & $29-94$ & $30-103$ & \\
\hline \multirow{2}{*}{$\begin{array}{c}\text { Restocetin agonists } \\
\text { test }\end{array}$} & Mean \pm SD & $60.6 \pm 26.12$ & $75.6 \pm 26.4$ & \multirow{2}{*}{$0.049 * \#$} \\
\hline & Range & $8-90$ & $30-110$ & \\
\hline
\end{tabular}

ADP: Adensoine DiPhosphate \# compared by Mann-Whitney test

PT, INR, BT showed insignificant differences between both groups except APTT that showed significant increase in cases group than control group $(\mathrm{P}<0.001)$

(Table 5).

Table (5): Bleeding profile in both groups

\begin{tabular}{|c|c|c|c|c|}
\hline \multicolumn{2}{|l|}{ Parameters } & $\begin{array}{c}\text { Cases } \\
(n=40) \\
\end{array}$ & $\begin{array}{l}\text { Control } \\
(\mathbf{n}=20)\end{array}$ & $P$ value \\
\hline \multirow{2}{*}{ Prothrombin time } & Mean \pm SD & $14.89 \pm 1.21$ & $14.4 \pm 0.6$ & \multirow{2}{*}{$>0.05$} \\
\hline & Range & $13-17$ & $13.5-15$ & \\
\hline \multirow{2}{*}{$\begin{array}{c}\text { International } \\
\text { normalization } \\
\text { ratio }\end{array}$} & Mean \pm SD & $1.11 \pm 0.1$ & $1.08 \pm 0.1$ & \multirow{2}{*}{$>0.05$} \\
\hline & Range & $0.9-1.3$ & $0.9-1.2$ & \\
\hline \multirow{2}{*}{$\begin{array}{l}\text { Activated partial } \\
\text { thromboplastin }\end{array}$} & Mean \pm SD & 65 & 35 & \multirow{2}{*}{$<0.001$} \\
\hline & Range & $24-80$ & $34-58$ & \\
\hline \multirow{2}{*}{ Bleeding time } & Mean \pm SD & $1.21 \pm 0.3$ & $1.2 \pm 0.41$ & \multirow{2}{*}{$>0.05^{\#}$} \\
\hline & Range & $1-2$ & $1-2$ & \\
\hline
\end{tabular}

PT: prothrombin time, APTT: activated partial thromboplastin, INR: international normalization ratio, BT: bleeding time, \# compared by Mann-Whitney test

Factor VIII activity was done in 35 cases of homphilia type A with mean \pm SD $25.06 \pm 31.86$, median 10 and range between 5 and $95 \%$. Factor IX activity was done in 5 cases of homphilia type $\mathrm{B}$ with mean $\pm \mathrm{SD}: 5.6 \pm 0.55$, and range between 5 and $6 \%$ (Table 6 ).

Table (6): Activity of factor VIII and factor IX in cases groups

\begin{tabular}{|c|c|c|}
\hline \multirow{2}{*}{$\begin{array}{c}\text { Factor VIII } \\
(\mathbf{n}=\mathbf{3 5})\end{array}$} & Mean \pm SD & $25.06 \pm 31.86$ \\
\cline { 2 - 3 } & Median & 10 \\
\hline Factor IX & Range & $5-95$ \\
$(\mathbf{n}=\mathbf{5})$ & Mean \pm SD & $5.6 \pm 0.55$ \\
\cline { 2 - 3 } & Range & $5-6$ \\
\hline
\end{tabular}

\section{DISCUSSION}

In our study, patients' characteristics (age, sex and weight) were comparable in both groups. As regard to type of hemophilia, the majority of cases $87.5 \%$ were type A and $12.5 \%$ were type B. This was supported by many studies found that hemophilia $\mathrm{A}$ is more common than hemophilia B. In most of the studies, hemophilia A constituted around $80 \%$ of 
total hemophilias (Ling et al., 2010, Uddin et al., 2010 and Karim et al., 2013). Mansouritorghabeh (2015) stated that hemophilia A or classical hemophilia accounts for about $80 \%$ of all hemophiliacs. Similarly, out of the total hemophilia patients, included in a study by Mishra et al. (2016), type A and B hemophilia patients were $88.3 \%$ and $11.7 \%$, respectively. The percentage of hemophilia type A patients was higher than type $B$ in both the age groups.

In our study, as regard to HSS, 7.5\% were type $1,47.5 \%$ were type 2 and $45 \%$ were type 3 .

Many scores were used to assess the severity of hemophilia symptoms. In study by Qasim et al. (2013), 43.13\% patients had severe degree of disease, $37.2 \%$ patients were diagnosed to have moderate degree of disease and $19.6 \%$ had mild disease.

Borhany et al. (2011) documented that majority of hemophiliacs had moderate severity $(52.0 \%)$ both in homphilia type A (HA) and homphilia type B (HB). Tonbary et al. (2010) showed that severe manifestations were reported in $76.7 \%$, followed by moderate severity in 17.2\%.2.

In our study, bleeding from the knee occurred in the majority of patients $(77.5 \%)$. From the elbow occurred in $32.5 \%$, from the ankle occurred in $5 \%$, from the vagina occurred in $15 \%$ and from the nose and the gum occurred in $7.5 \%$.

In agreement with the present study, Sharma et al. (2016), 38.8\% had no complaints related to the disease. $61.11 \%$ presented with manifestations such as bleeding from soft tissues or joints, swelling or pain the joints etc. Knee is most common site of repetitive bleeding and hemarthrosis followed by ankle $(27.27 \%) .12 .03 \%$ had involvement of more than one joints, while $6.06 \%$ presented with bleeding from gums.

In harmony with current study, Qasim et al. (2013) reported that, clinical features included prolonged bleeding after injury in $98 \%$ of patients, and $90 \%$ had hematomas at different body sites. Hemarthrosis (bleeding in the joints) was noted in $86 \%$ of the patients. Rest of the patients had prolonged bleeding after tooth extraction, epistaxis, bleeding from gums, deep bleeding, malena and hematuria. Knee joint was the most commonly involved joint $(47.83 \%$ episodes).

In our study, platelets and maual platelet count showed insignificant difference between both groups. This correlated with a study done by Sadaria et al. (2016) who showed that platelet count of all patients was ranging from 1,50,000 to $491,000 / \mathrm{cmm}$ which was within normal range.

In our study, hemoglobin was significantly lower in the cases group than the control group, which correlated well with study done by Sinha et al. (2012) showing hemoglobin was significantly lower in $25 \%$ of cases. This decrease in hemoglobin could be explained by loss of blood due to repeated bleeding episodes. Ahmed et al. (2015) stated that patients with hemophilia are more prone for iron deficiency and presents with iron deficiency anaemia.

Moreover, Poongavanam et al. (2017) showed that iron deficiency is common in patients with hemophilia, and it is related with increased severity of the disease due 
to repeated episodes of spontaneous bleeding.

In disaccordance with our study, a retrospective study by Hoffman and Monroe (2010) found haemoglobin count of patients with hemophilia A and B ranged from $6 \mathrm{~g} \%$ to $14.2 \mathrm{~g} \%$. Another different result was reported by Parthiban et al. (2015) showed that, the hemoglobin level of patients with hemophilia A ranged from $7.8 \mathrm{~g} \%$ to $14.6 \mathrm{~g} \%$ and for hemophilia B ranged from $9.6 \mathrm{~g} \%$ to 12.8 $\mathrm{g} \%$.

In our study, platelets aggregation tests (ADP test, collagen and restocetin agonists test) were significantly lower in cases group than control group. These findings were indicative of a concomitant platelet function defect in severe hemophilia. As baseline and poststimulation expression of a-granular $\mathrm{P}$ selection and d-granular CD 63 were similar in hemophiliacs and controls. Acquired storage pool deficiency is regarded an unlikely cause for the reduced platelet reactivity. Platelet-collagen interaction is mediated via the glycoprotein (GP) receptor Ia/IIa (a2b1 integrin), and the immunoglobulin superfamily receptor GP VI. The role of further potential collagen receptors remains to be determined. GP Ia/IIa and GP VI are constitutively expressed on the platelet surface in relatively low numbers, with a well-recognized up to 10-fold variation of the GP Ia/IIa expression occurring normally. GP Ia/ IIa has a major role in platelet adhesion and anchoring. GP VI is principally responsible for signaling and platelet activation. The activation of GP VI facilitates the binding of collagen to GP Ia-IIa.39,40
Deficiencies of GP Ia/IIa and GP VI are associated with decreased platelet adhesion and manifest as a mild bleeding disorder (Maziri et al., 2016) Similarly, Tarandovskiy et al. (2013) demonstrated through thromboelastography that platelet activity was involved in hemophilia phenotype and significantly changed.

In disagreement with current study, van Bladel et al. (2011) stated that the percentages of activated platelets after maximal ADP stimulation in all patients with hemophilia were comparable to those in healthy controls. They found that platelet responsiveness to ADP stimulation of patients with severe hemophilia and mild-moderate hemophilia did not differ from that of healthy controls for patients with severe and mildmoderate hemophilia, respectively.

In our study, Prothrombin time (PT), International normalization ratio (INR), and bleeding time (BT) showed insignificant differences between both groups. On the other hands, Activated partial thromboplastin time (APTT) significantly prolonged cases group than control group. This supported the view that the clotting time is not recommended as a reliable indicator of abnormal haemostasis and may be normal even in severe hemophilia as suggested by various authors

This correlated well with study done by Sadaria et al. (2016) which stated that PT is normal in all patients with hemophilia as extrinsic pathway is intact in hemophilia.

APTT was prolonged in all cases of hemophilia A and B with an average of 88 sec, similar to the mean APTT value of 80 seconds as reported by Jennings et al. 
(2013). Also, the prolonged APTT values correlated with Uddin et al. (2010). The prolonged APTT with normal PT and bleeding time are typical findings in study by Lippi et al. (2012) which in line with our study.

In accordance with our study, a retrospective study by Hoffman and Monroe (2010) found that Prothrombin time was normal in all of these patients. Taki and Shirahata (2012) found that APTT prolonged in all the patients with hemophilia as it involves disruption of the intrinsic pathway of coagulation.

In accordance with our study, retrospective study by Sadaria et al. (2016) found Factor VIII level reduced $(<50 \%)$ in all patient of hemophilia A. Normal range for factor VIII was $50 \%$ to $150 \%$. Factor IX level reduced $(<50 \%)$ in all patient of hemophilia $\mathrm{B}$.

\section{CONCLUSION}

Diagnosis of hemophilia is confirmed by factor VIII assay for hemophilia A and factor IX assay for hemophilia B.

\section{REFERENCES}

1. Ahmed SG, Kagu MB and Ibrahim UA. (2015): The frequency of iron deficiency among patients with hemophilia-A in northern Nigeria: correlation with the disease severity and clinical implications. The Egyptian Journal of Haematology, 40: 85-93.

2. Borhany M, Shamsi T, Naz A, Farzana T and Ansari S. (2011): Congenital bleeding disorders in Karachi, Pakistan. Clinical and Applied Thrombosis/Hemostasis, 17: 131-7.

3. Faircloth JM, Roe O and Alsaied T. (2017): Intermediate term thrombotic risk in contemporary total cavo-pulmonary connection for single ventricle circulations. J Thromb Thrombolysis, 44: 275-80.
4. Hoffman M and Monroe III DM (2010): A cell-based model of hemostasis. Thrombosis and haemostasis, 85: 958-65.

5. Jennings I, Kitchen DP, Kitchen $S$ and Bonar R. (2013): Investigation of a prolonged APTT. Different approaches taken by laboratories to achieve the same diagnosis. Int J Lab Hematol., 35: 177-82.

6. Karim M, Siddique R, Jamal $\mathbf{C}$ and Islam A. (2013): Clinical profile of hemophilia in children in a tertiary care hospital. Bangladesh Journal of Child Health, 37: 90-6.

7. Ling S, Chan G, Shing $M$ and Lee KS (2010): Children and Adolescents with Hemophilia in Hong Kong: An Epidemiological and Clinical Review. HK J Paediatr (new series), 11: 13-9.

8. Lippi G, Meschi T and Borghi L (2012): Variation of activated partial thromboplastin time according to age and sex in a large population study: analytical and clinical implications. Blood Coagulation \& Fibrinolysis, 23: 177-8.

9. Lyde R, Sabatino D and Sullivan S. (2015): Platelet-delivered therapeutics. Journal of Thrombosis and Haemostasis, 13: S143-S50.

10. Mansouritorghabeh $H$ (2015): Clinical and laboratory approaches to hemophilia A. Iranian Journal of Medical Sciences, 40: 194.

11. Maziri P, Asaadi Tehrani $G$ and Mirzaahmadi S (2016): Relationship between GPIa $(807 \mathrm{C} / \mathrm{T})$ and GPIIIa (PLA1/PLA2) gene plymorphisms and recurrent spontaneous abortion in women in Tehran Province. Scientific Journal of Iran Blood Transfus Organ, 13: 138-45.

12. Mishra S, Kumar S, Panwar A, Bhagchandani D and Aneja GK. (2016): A clinical profile of hemophilia patients and assessment of their quality of life in Western Uttar Pradesh, India: An observational study. Medical Journal of Dr. D.Y. Patil University, 9: 320-4.

13. Parthiban R, Kaler AK and Sangeeta $M$. (2015): A clinico-pathological study of hemophilia in rural set up of Karnataka. Journal of Advances in Medicine and Medical Research, 38: 948-55. 
14. Poongavanam $P$, Nandakumaran $J$ and Shanmugam M. (2017): The frequency of iron deficiency among patients with hemophilia. IOSR Journal of Dental and Medical Sciences (IOSRJDMS), 16: 04-9.

15. Qasim Z, Naseem $\mathbf{L}$, Asif $\mathbf{N}$ and Hassan $\mathbf{K}$. (2013): Hemophilia: pattern of clinical presentation and disease severity. Int J Pathol., 11: 58-63.

16. Sadaria T, Goswami $H$ and Patel S (2016): Study of laboratory parameters in hemophilia patients. Int J Cur Res Rev., 8: 46-52.

17. Sharma RS, Arya AK and Rao YK (2016): Clinico-epidemiological profile of hemophilia with special reference to development of inhibitors in Indian scenario: a crosses sectional study at tertiary care centre in north India, 3: 4-9.

18. Sinha, N., Mishra, T. K., Singh, T., and Gupta, N. (2012): Effect of iron deficiency anemia on hemoglobin A1c levels. Annals of laboratory Medicine, 32(1), 17-22.

19. Taki M and Shirahata A (2012): Current situation of regular replacement therapy (prophylaxis) for hemophilia in Japan. Hemophilia, 15: 78-82.

20. Tarandovskiy ID, Balandina AN and Kopylov KG. (2013): Investigation of the phenotype heterogeneity in severe hemophilia A using thromboelastography, thrombin generation, and thrombodynamics. Thrombosis Research, 131: 274-80.

21. Tonbary YA, Elashry $R$ and Zaki MES (2010): Descriptive epidemiology of hemophilia and other coagulation disorders in mansoura, egypt: retrospective analysis. Mediterranean Journal of Hematology and Infectious Diseases, 2: 18-26.

22. Traivaree $C$, Blanchette $\mathbf{V}$ and Armstrong D. (2011): Intracranial bleeding in hemophilia beyond the neonatal period--the role of CT imaging in suspected intracranial bleeding. Hemophilia, 13: 552-9.

23. Uddin M, Rahman $M$ and Rahman $M$. (2010): Clinico-pathological study on hemophilia: An analysis of 50 cases. Journal of Bangladesh College of Physicians and Surgeons, 24: 50-3.

24. van Bladel ER, Schutgens REG, Fischer K, de Groot PG and Roest M. (2014): Platelet degranulation and glycoprotein IIbIIIa opening are not related to bleeding phenotype in severe hemophilia A patients. Thrombosis and Haemostasis, 111: 1022-30. 


\section{در اسة تأثير إعتلال الصفائح الدموية على النمط الظاهري السريري للهيموفيليا}

محمد خليل محمد عبدالله، محمود محمد موسى بازيد، أحمد على على عاصم*, محمود عبد الرشيد عبد الخالق

قسمي الأمراض الباطنة والباثولوجيا الإكلينيكيةث، كلية الطب، جامعة الأزهر

\section{E-mail: $\underline{\text { dr4667294@gmail.com }}$}

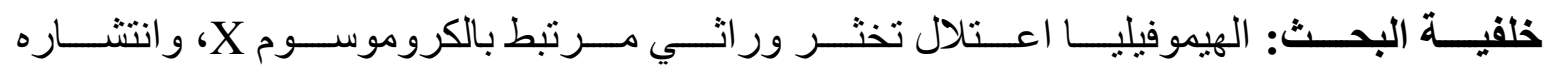

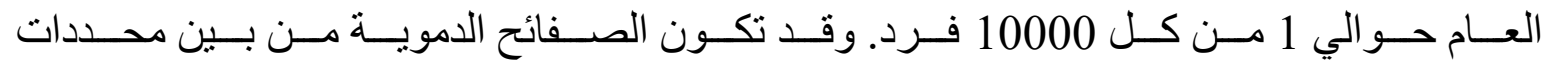
التباين في النمط الظاهري للنزيف.

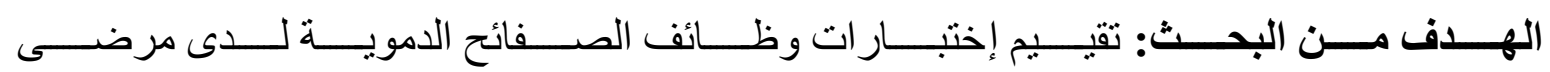
الهيموفيليا و إستكثاف تأثثير ضعف الصفائح الدموية على درجة نزيف الهيموفيليا.

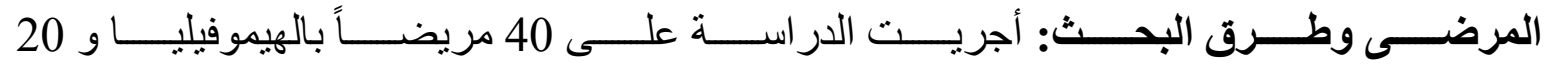

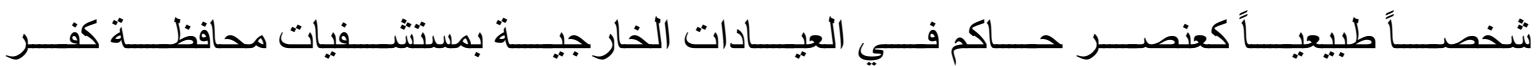

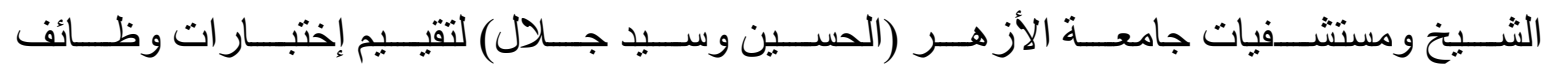

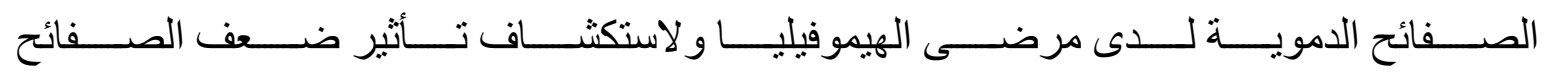
الدموية على درجة نزيف الهيموفيليا.

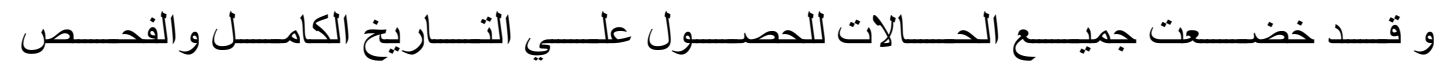

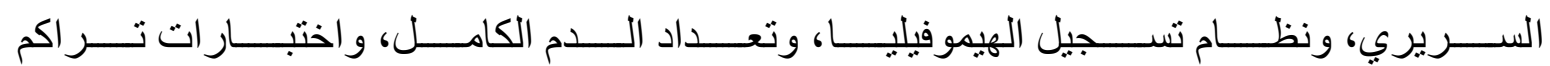

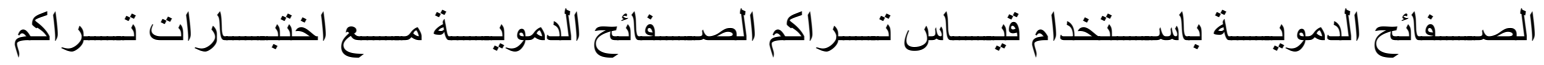

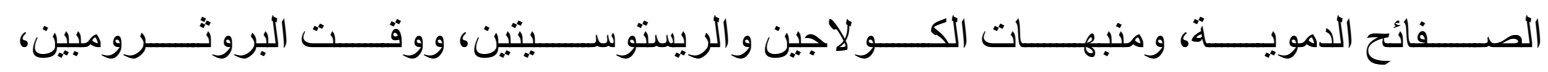

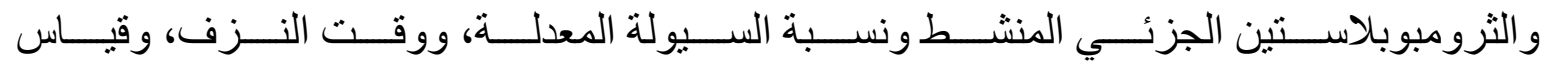

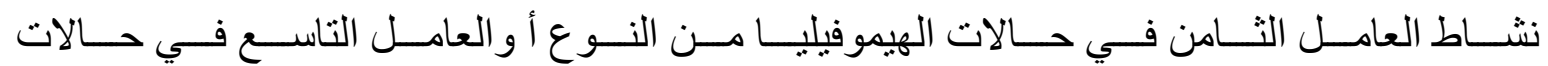
الهيموفيليا من النوع ب.

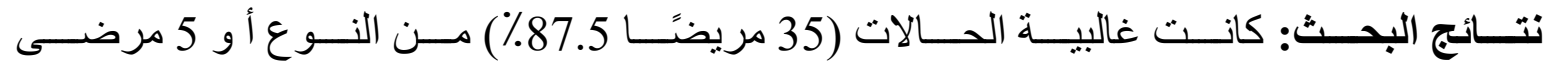

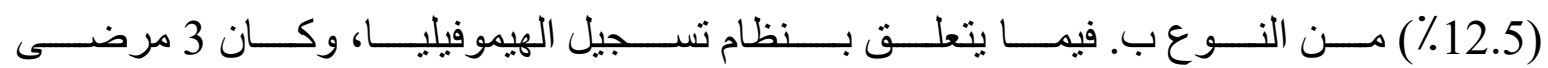




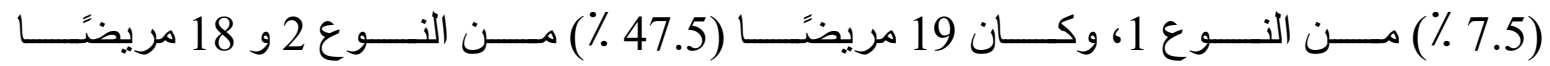

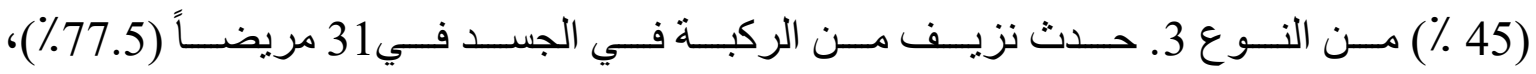

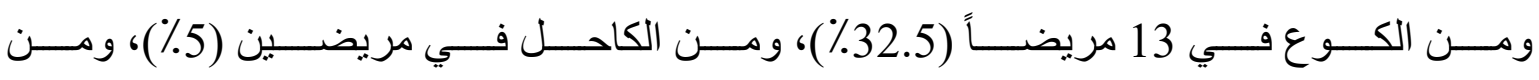

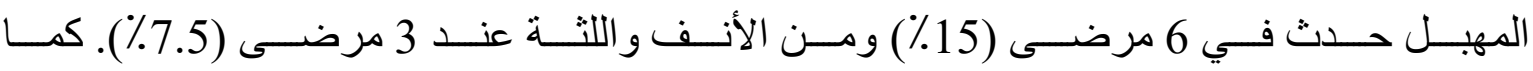

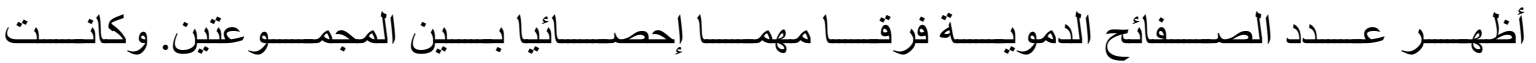

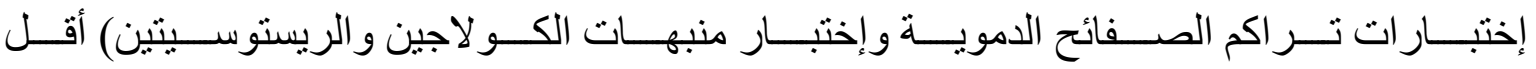

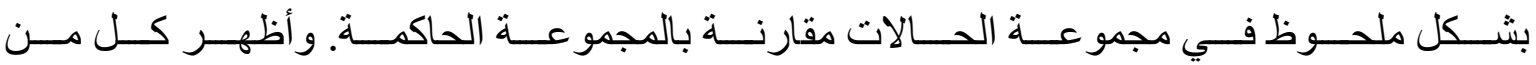

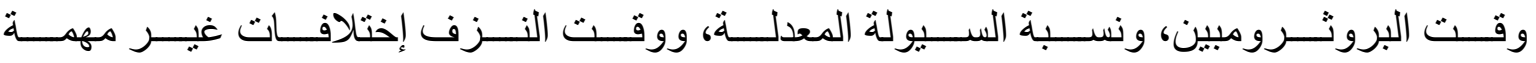

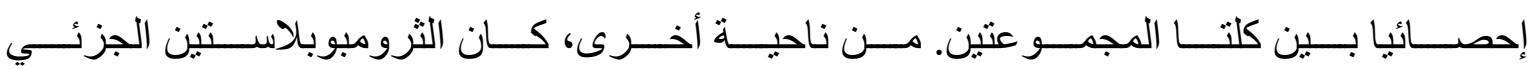

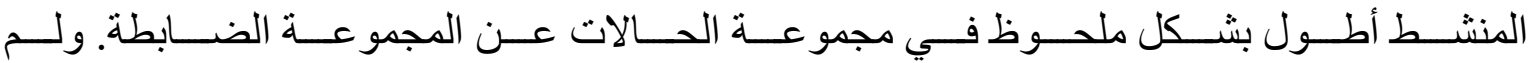
يتم الكثف عن حالات هيموفيليا ج في در استنا.

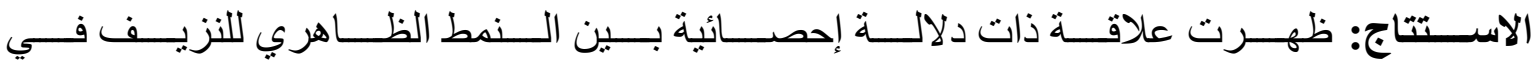

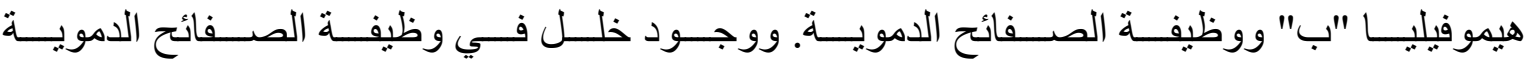

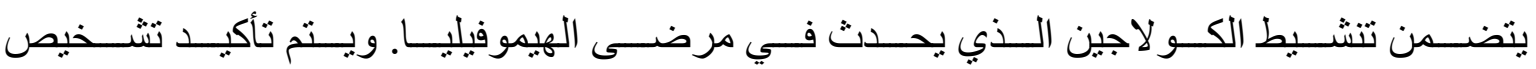

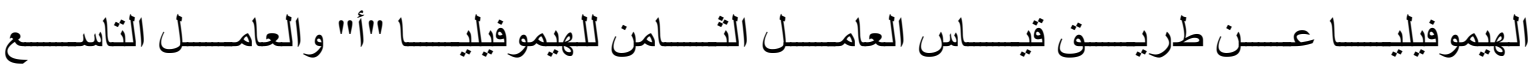

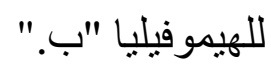

الكلمات الدالة: الهيموفيليا، ضعف الصفائح الدموية، النمط الظاهري السريري. 